\title{
Peran Pencapaian Tujuan Bumdes Mandiri Jaya dalam Pengelolaan Dana Desa
}

\author{
Putri Ayu Lestari ${ }^{1 *}$, Aprina Nugrahesthy Sulistya Hapsari ${ }^{2}$
}

1,2,Fakultas Ekonomika dan Bisnis, Universitas Kristen Satya Wacana Salatiga

\section{A R T I C L E I N F O}

Article history:

Received 01 December 2019

Received in revised form

31 December 2019

Accepted 15 January 2020

Available online 26

February 2020

\section{Kata Kunci:}

Peran, Desa dan Dana Desa,

Badan Usaha Milik Desa (BUMDes

Keywords:

Role, village and village

funds, village-owned

enterprises (BUMDes).

\section{A B S T R A K}

Tujuan dari penelitian mendiskripsikan peran BUMDes Mandiri Jaya dalam mengelola dana desa di Desa Sepakung, Kabupaten Semarang. Teori yang digunakan dalam penelitian ini teori desa dan dana desa serta teori Badan Usaha Milik Desa (BUMDes). Jenis penelitian kualitatif dengan teknik pengumpulan data wawancara mendalam dan dokumentasi. Teknik analsis data penelitian ini menggunakan teknik triangulasi. Teknik triangulasi adalah teknik pemeriksa keabsahan data atau kebenaran data dengan melalui langkah - langkah yang terdiri dari: reduksi, penyajian data, dan penarikan kesimpulan. Hasil penelitian menunjukkan bahwa peran BUMDes Mandiri Jaya secara umum sudah dilakukan sesuai dengan Peraturan Menteri Desa Pembangunan Daerah Tertinggal, dan Transmigrasi Republik Indonesia Nomor 4 Tahun 2015 Pasal 2. Namun dilihat dari seluruh perannya, analisis yang dilakukan masih terdapat kendala dalam implementasi peran BUMDes Mandiri Jaya antara lain: belum terlaksannya wadah penyalur hasil pertanian desa ke pasar tradisional, kurangnya pemahaman pengelola tentang BUMDes, keberadaan BUMDes Mandiri belum diketahui oleh masyarakat sekitar, terbatasnya modal yang dimiliki oleh BUMDes Mandiri Jaya, serta kendala dalam menemukan kesepakatan bersama untuk ide pengembangan objek wisata yang di Desa Sepakung. Bagi penelitian selanjutnya diharapkan melakukan identifikasi kendala secara lebih detail dalam pengelolaan BUMDes serta memperluas narasumber guna untuk mendapatkan informasi yang lengkap.

\section{A B S T R A C T}

The purpose of the research is to describe the role of BUMDes Mandiri Jaya in managing the village funds in the village of soccer, Semarang regency. The theory used in this study was the village theory and village funds as well as the theory of village-owned enterprises (BUMDes). This type of qualitative research with deep interview data collection techniques and documentation. This research data analytic technique uses triangulation technique. The triangulation technique is a data validity checker technique or data correctness by going through step-by-step consisting of: reduction, data presentation, and conclusion withdrawal. The results showed that the role of BUMDes Mandiri Jaya was generally conducted in accordance with the regulation of the Minister of Rural Development, and transmigration of the Republic of Indonesia No. 4 year 2015 article 2. But seen from all roles, the analysis is still there are constraints in the implementation of the role of BUMDes Mandiri Jaya, among others: not yet the flow of the village agricultural distributor to the traditional market, lack of management understanding about BUMDes, the existence of BUMDes Mandiri is not known by the surrounding community, limited capital owned by BUMDes Mandiri Jaya, as well as obstacles in finding a joint agreement for the idea of development of tourism objects in the village. Further research is expected to identify constraints in more detail in the management of BUMDes and expand the resource to obtain complete information.

Copyright @ $@$ Universitas Pendidikan Ganesha. All rights reserved.

\footnotetext{
* Corresponding author.

E-mail addresses: a232015262@student.uksw.edu (Putri Ayu Lestari)
} 


\section{Pendahuluan}

Keberadaan BUMDes (Badan Usaha Milik Desa) berhasil menggerakkan ekonomi desa. Salah satu BUMDes yang berhasil menggerakkan ekonomi berada di Desa Ponggok Kecamatan Polan Harjo, Kabupaten Klaten dengan sukses menghasilkan pendapatan asli desa sebesar Rp5 miliar yang berfokus pada wisata air (Nazar 2016). Undang - Undang Nomor 6 tahun 2014 memiliki maksud bahwa sebuah desa dapat berdiri secara mandiri dan dapat mengelola perekonomiannya secara mandiri, namun faktanya berbeda karena ternyata justru terdapat fenomena kecurangan pengelolaan dana desa yang dapat merugikan negara dan juga masyarakat desa. Sebagai contoh adalah kasus kecurangan yang terjadi di Desa Purwosari, Kecamatan Natar, Kabupaten Lampung Selatan karena tidak benar dalam mengelola dana desa yang harusnya untuk kepentingan masyarakat desa, tetapi untuk kepentingan pribadi. Kecurangan ini dilakukan oleh Agus Wahyono (Kades) dengan mengambil dana desa dari salah seorang pengurus BUMDes tahun 2016 sebesar Rp60 juta dan ditahun 2017 sebesar Rp82 juta yang digunakan untuk kepentingannya bukan untuk kepentingan masyarakat desa (Ida 2016). Kasus lain terjadi di Desa Tubmonas, Kecamatan Kuatnana, Kabupaten TTS, sembilan warga datang ke kejaksaan untuk melaporkan dugaan penyelewengan dana BUMDes dan dana desa yang dilakukanoleh kepala desa. Warga merasa janggal karena di Desa Tubmonas belum memiliki BUMDes, namun di dalam SPJ terdapat dana yang terpakai sebesar Rp 150 juta. Dana tersebut diduga digunakan oleh kepala desa untuk membeli satu unit mobil truk bak kayu (Irvan 2019).

Penelitian terkait BUMDes dilakukan oleh Kurniasih (2014) yang menyatakan bahwa pengelolaan yang dilakukan oleh BUMDes belum baik karena kinerja BUMDes belum mencapai nilai efisien dan efektif, ekonomi, dan responsibilitas serta pemberdayaan masyarakat yang ditunjukkan dengan kurangnya pemanfaatan dan pengelolaan sumber daya lokal desa. Selain itu penelitian menurut Ramadana, Ribawanto, and Suwondo (2013) dalam penelitiannya menyatakan keberadaan BUMDes dapat membantu penguatan ekonomi Desa Landungsari, Kecamatan Dau, Kabupaten Malang, meskipun terdapat kelemahan bahwa sumber - sumber dana untuk peningkatan pendapatan desa oleh BUMDes masih belum dapat dikatakan memenuhi pendapatan desa dan terdapat kesulitan pada modal sehingga belum mampu berkontribusi secara baik dalam memenuhi kebutuhan masyarakat. Penelitian yang dilakukan oleh Hayyuna, Pratiwi, and Mindarti (2014) yang menyatakan bahwa BUMDes Desa Sepakuk, Kabupaten Gresik sudah berkontribusi untuk perekonomian desa dan dapat meningkatkan pendapatan desa, tetapi terdapat kelemahan Desa Sepakuk yaitu belum memiliki website, karena menurut penelitian bahwa dengan adanya website dapat membantu pemasaran Desa Wisata Sepakuk, Kabupaten Gresik dan mempermudah desa lain untuk melihat produk apa saja yang dimiliki oleh BUMDes Sepakuk, Kabupaten Gresik. Tidak hanya itu penelitian oleh Agunggunanto and Darwanto (2016) dalam hasil penelitiannya menjelaskan BUMDes mengalami masalah pada keterbatasan modal sehingga menyarankan untuk mengajukan bantuan modal pada pihak ketiga agar dapat membantu, selain itu terdapat kendala pada kurangnya pemahaman masyarakat mengenai BUMDes, maka perlu diadakan sosialisasi untuk masyarakat agar mengetahui pentingnya partisipan dalam program atau produk BUMDes untuk membantu meningkatkan pendapatan dan perekonomian desa.

Berdasarkan latar belakang tersebut, maka penelitian ini bermaksud ingin mendiskripsikan peran BUMDes Mandiri Jaya dalam mengelola dana desa di Desa Sepakung, Kabupaten Semarang. Dalam upayanya mencapai tujuan alasan pemilihan BUMDes Mandiri Jaya di Desa Sepakung karena BUMDes Mandiri Jaya sudah berdiri lebih dari tiga tahun, selain itu Desa Sepakung dulu dikenal sebagai desa tertinggal kini sudah menjadi desa yang sangat berkembang dan bahkan menjadi nominasi desa wisata terbaik pada tahun 2016 yang diselenggarakan oleh Pemerintah Provinsi Jawa Tengah, dengan salah satu syarat atau kriteria penilaian yaitu Desa Sepakung sudah memiliki BUMDes.

Penelitian ini diharapkan bermanfaat yang pertama bagi BUMDes Mandiri Jaya di Desa Sepakung, Kabupaten Semarang untuk membantu mengevaluasi peran terkait peran BUMDes dalam kaitannya untuk pencapaian tujuan BUMDes Mandiri Jaya khususnya dalam pengelolaan keuangannya. Kedua bagi pemerintah untuk membantu memberikan masukkan kepada pemerintah terkait kebijakan pengelolaan keuangan BUMDes agar lebih transparan karena BUMDes dibentuk untuk membantu desa dalam mengelola keuangan desa dan usaha desa. Ketiga untuk masyarakat penelitian ini memiliki manfaat untuk membantu masyarakat dalam melihat dan menilai peran BUMDes Mandiri Jaya di Desa Sepakung dalam membantu kemajuan ekonomi masyarakat Desa Sepakung. Terakhir untuk akademisi yaitu untuk menambah pengetahuan tentang peran BUMDes yang nantinya dapat menjadi bahan penelitian selanjutnya.

Desa merupakan representasi dari kesatuan masyarakat hukum terkecil yang telah ada dan tumbuh berkembang seiring dengan sejarah kehidupan masyarakat Indonesia dan menjadi bagian yang tidak terpisahkan dari tatanan kehidupan bangsa Indonesia. Sebagai wujud pengakuan negara terhadap desa, 
khususnya dalam rangka memperjelas fungsi dan kewenangan desa, serta memperkuat kedudukan desa dan masyarakat desa sebagai subjek pembangunan, diperlukan kebijakan penataan dan pengaturan mengenai desa yang diwujudkan dengan lahirnya UU Nomor 6 Tahun 2014 tentang Desa (Pemerintah Republik Indonesia 2014).

Menurut Undang - Undang No 6 Tahun 2014 Pemerintah Republik Indonesia (2014) desa adalah desa dan desa adat atau yang disebut dengan nama lain, selanjutnya disebut desa, adalah kesatuan masyarakat hukum yang memiliki batas wilayah yang berwenang untuk mengatur dan mengurus urusan pemerintahan, kepentingan masyarakat setempat berdasarkan prakarsa masyarakat, hak asal usul, dan/atau hak tradisional yang diakui dan dihormati dalam sistem pemerintahan Negara Kesatuan Republik Indonesia. Sedangkan menurut Peraturan Pemerintah Republik Indonesia No 60 Tahun 2014 Pemerintah Republik Indonesia (2014) dana desa adalah dana yang sumbernya berasal dari Anggaran Pendapatan dan Belanja Negara yang diperuntukkan bagi desa yang ditransfer melalui Anggaran Pendapatan dan Belanja Daerah Kabupaten/Kota dan digunakan untuk membiayai penyelenggaraan pemerintahan, pelaksanaan pembangunan, pembinaan kemasyarakatan, dan pemberdayaan masyarakat. Tetapi jumlah dana yang diberikan untuk tiap desa berbeda sesuai dengan geografis desa, jumlah penduduk, dan tingkat angka kematian. Adanya penyaluran dana desa ini nantinya akan meningkatkan pendapatan desa, dengan meningkatnya pendapatan desa yang diterima dari Anggaran Pendapatan dan Belanja Negara maka juga harus terdapat laporan pertanggung jawaban dari desa dalam pengelolaan dana tersebut.

Berdirinya Badan Usaha Milik Desa dilatarbelakangi oleh pembangunan ekonomi adil dan merata. Adanya potensi sumber daya yang melimpah, mendorong pemerintah untuk mengajak desa mendirikan Badan Usaha Milik Desa atau yang disebut BUMDes. Menurut Peraturan Menteri Desa, Pembangunan Daerah Tertinggal, dan Transmigrasi Republik Indonesia Nomor 4 Tahun 2015 pasal (1) Pemerintah Republik Indonesia (2015), Badan Usaha Milik Desa yang selanjutnya disebut BUMDes, adalah badan usaha yang seluruh atau sebagian besar modalnya dimiliki oleh desa melalui penyertaan secara langsung yang berasal dari kekayaan desa yang dipisahkan guna mengelola aset, jasa pelayanan, dan usaha lainnya untuk sebesar-besarnya kesejahteraan masyarakat desa. Pendirian BUMDes sebagai wadah untuk menampung semua kegiatan desa di bidang ekonomi ataupun pelayanan masyarakat dalam pengelolaannya dilakukan oleh desa bahkan dapat juga dilakukan kerja sama antar desa. Pendirian BUMDes juga tidak lepas dari tujuan pemerintah untuk mengembangkan sebuah desa seperti yang dijelaskan di Peraturan Menteri Desa, Pembangunan Daerah Tertinggal, dan Transmigrasi Republik Indonesia Nomor 4 Tahun 2015 pasal (2) Pemerintah Republik Indonesia (2015) pendirian BUMDes yaitu: (1) meningkatkan perekonomian desa; (2) mengoptimalkan aset desa agar bermanfaat untuk kesejahteraan desa; (3) meningkatkan usaha masyarakat dalam pengelolaan potensi ekonomi desa; (4) mengembangkan rencana kerja sama usaha antar desa dan/atau dengan pihak ketiga; (5) menciptakan peluang dan jaringan pasar yang mendukung kebutuhan layanan umum warga; (6) membuka lapangan kerja; (7) meningkatkan kesejahteraan masyarakat melalui perbaikan pelayanan umum, pertumbuhan dan pemerataan ekonomi desa; (8) meningkatkan pendapatan masyarakat desa dan Pendapatan Asli Desa.

Peranan BUMDes berada pada bidang ekonomi dan bidang sosial. Peran dalam bidang ekonomi yaitu membantu desa untuk dapat meningkatkan kesejahteraan masyarakat dengan adanya usaha yang dimiliki oleh BUMDes dan dapat ikut serta berkontribusi terhadap kas desa maupun pendapatan asli desa. Sedangkan peran di bidang sosial yaitu dapat memberdayakan masyarakat, memajukan komunikasi dan kebersamaan dengan BUMDes yang telah ada sampai sekarang melalui kegiatan yang ada. Peranan BUMDes ini juga tercantum di dalam Undang - Undang Republik Indonesia Nomor 6 Tahun 2014 tentang desa pasal (89) Pemerintah Republik Indonesia (2014) bahwa hasil dari BUMDes dimanfaatkan selain untuk pengembangan desa, dan pemberdayaan masyarakat desa, dan pemberian bantuan untuk masyarakat miskin melalui hibah, bantuan sosial, dan kegiatan dana bergulir yang ditetapkan dalam APB Desa.

Pendirian BUMDes harus berpedoman dengan peraturan desa tentang pendirian desa dengan Peraturan Menteri Desa, Pembangunan Daerah Tertinggal, dan Transmigrasi Republik Indonesia Nomor 4 Tahun 2015 pasal 5 Pemerintah Republik Indonesia (2015) yaitu : (1) inisiatif Pemerintah Desa dan/atau masyarakat desa; (2) potensi usaha ekonomi desa; (3) sumberdaya alam di desa; (4) sumberdaya manusia yang mampu mengelola BUMDes; dan (5) penyertaan modal dari Pemerintah Desa dalam bentuk pembiayaan dan kekayaan desa yang diserahkan untuk dikelola sebagai bagian dari usaha BUMDes.

Penyertaan modal awal BUMDes berasal dari APB Desa yang terdiri dari penyertaan modal desa dan penyertaan modal masyarakat desa. Modal desa berasal dari : (1) hibah dari pihak swasta, lembaga sosial ekonomi kemasyarakatan dan/atau lembaga donor yang disalurkan melalui mekanisme APB Desa; (2) bantuan Pemerintah, Pemerintah Daerah Provinsi, dan Pemerintah Daerah Kabupaten/Kota yang 
disalurkan melalui mekanisme APB Desa; (3) kerjasama usaha dari pihak swasta, lembaga sosial ekonomi kemasyarakatan dan/atau lembaga donor yang dipastikan sebagai kekayaan kolektif desa dan disalurkan melalui mekanisme APB Desa; (4) aset desa yang diserahkan kepada APB Desa sesuai dengan ketentuan peraturan perundang-undangan tentang aset desa menurut Peraturan Menteri Desa, Pembangunan Daerah Tertinggal, dan Transmigrasi Republik Indonesia Nomor 4 Tahun 2015 pasal (18) (Pemerintah Republik Indonesia 2015).

Menurut Peraturan Menteri Desa, Pembangunan Daerah Tertinggal, dan Transmigrasi Republik Indonesia Nomor 4 Tahun 2015 bab III pasal 10 Pemerintah Republik Indonesia (2015) anggota BUMDes terdiri dari penasehat, pelaksana operasional,dan pengawas juga dapat dilihat pada Gambar 1 .

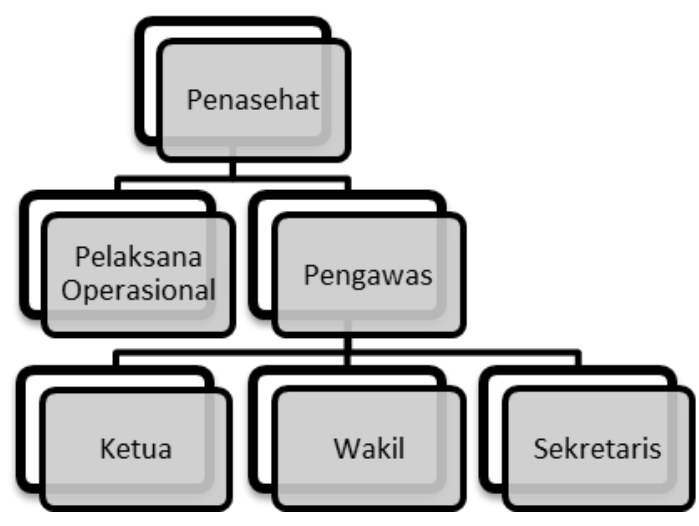

Gambar 1. Struktur Organisasi BUM Desa

Sumber: Peraturan Menteri Desa, Pembangunan Daerah Tertinggal, dan Transmigrasi Republik Indonesia Nomor 4 Tahun 2015

Gambar 1 menjelaskan tentang struktur organisasi BUMDes yang terdiri dari Penasehat, Pelaksana Operasional, dan Pengawas. Tugas dan wewenang dari setiap struktur organisasi BUMDes menurut Peraturan Menteri Desa, Pembangunan Daerah Tertinggal, dan Transmigrasi Republik Indonesia Nomor 4 Tahun 2015 Pemerintah Republik Indonesia (2015) yaitu Penasehat seperti yang terdapat pada pasal 10 huruf a dijabat oleh ex officio oleh Kepala Desa yang bersangkutan. Penasehat memiliki beberapa tujuan yang harus dijalankan yaitu memberikan nasihat kepada Pelaksana Operasional dalam melaksanakan pengelolaan BUMDes, memberikan saran dan pendapat mengenai masalah yang dianggap penting bagi pengelolaan BUMDes, mengendalikan pelaksanaan kegiatan pengelolaan BUMDes. Selain itu seorang Pelaksana Operasional juga memiliki wewenang untuk meminta penjelasan dari Pelaksana Operasional mengenai persoalan yang menyangkut pengelolaan usaha desa dan melindungi usaha desa terhadap halhal yang dapat menurunkan kinerja BUMDes.

Kedua, Pelaksana Operasional memiliki tugas dan mengurus dan mengelola BUMDes sesuai dengan Anggaran Dasar dan Anggaran Rumah Tangga sesuai dengan Peraturan Menteri Desa, Pembangunan Daerah Tertinggal, dan Transmigrasi Republik Indonesia Nomor 4 Tahun 2015 pasal 10 Pemerintah Republik Indonesia (2015) berkewajiban melaksanakan dan mengembangkan BUMDes agar menjadi lembaga yang melayani kebutuhan ekonomi dan /atau pelayanan umum masyarakat desa, menggali dan memanfaatkan potensi usaha ekonomi desa untuk meningkatkan Pendapatan Asli Desa, dan melakukan kerjasama dengan lembaga - lembaga perekonomian desa lainnya. Pelaksana Operasional juga berwenang untuk membuat laporan keuangan seluruh unit - unit usaha BUMDes setiap bulan, membuat laporan perkembangan unit - unit usaha BUMDes kepada masyarakat desa melalui musyawarah desa sekurang kurangnya 2 (dua) kali dalam 1 (satu) tahun.

Terakhir, Pengawas sebagaimana dimaksud dalam Peraturan Menteri Desa, Pembangunan Daerah Tertinggal, dan Transmigrasi Republik Indonesia Nomor 4 Tahun 2015 pasal 10 ayat (1) huruf c Pemerintah Republik Indonesia (2015) bahwa pengawas memiliki kewajiban menyelenggarakan Rapat Umum untuk membahas kinerja BUMDes sekurang - kurangnya 1 (satu) tahun sekali. Berwenang untuk menyelenggarakan Rapat Umum Pengawas untuk pemilihan dan pengangkatan pengurus sebagaimana dimaksud pada ayat (2), penetapan kebijakan pengembangan kegiatan usaha dari BUMDes, dan pelaksanaan pemantauan dan evaluasi terhadap kinerja pelaksana operasional. 


\section{Metode}

Penelitian ini adalah deskriptif kualitatif yang dilakukan di BUMDes Mandiri Jaya yang terletak di Desa Sepakung, Kec.Banyubiru, Kabupaten Semarang, Jawa Tengah. Jenis data yang akan digunakan adalah jenis data primer. Data primer diperoleh secara langsung dari hasil wawancara mendalam dan didukung dengan dokumentasi. Narasumber dalam penelitian adalah pengelola BUMDes Mandiri Jaya, wawancara dilakukan dengan Bapak Susiyanto selaku penanggung jawab pengelola serta bendahara yaitu Ibu Atik Rahmawati. Wawancara dengan pengelola BUMDes Mandiri Jaya untuk mendapatakan informasi mengenai program - program BUMDes untuk membantu meningkatkan perekonomian Desa Sepakung. Untuk mendapatkan informasi yang lengkap wawancaara yang dilakukkan selain dengan pengelola BUMDes Mandiri Jaya penelitian ini juga melakukan wawancara dengan perwakilan masyarakat yang dinilai memahami pengelolaan keuangan BUMDes Mandiri Jaya. Wawancara dengan warga dilakukan kepada Bapak Ngusman dusun Krajan selaku pengurus balai desa, Ibu Aminah dusun Krajan, Ibu Siti dusun Jingkol, Bapak Didik selaku pengelola wisata Gumuk Reco, dan Bapak Mustofa pengelola Cemoro Sewu.

Teknik analsis data penelitian ini menggunakan teknik triangulasi. Teknik triangulasi adalah teknik pemeriksaan keabsahan data atau kebenaran data dengan melalui tahapan - tahapan yang terdiri dari: reduksi, penyajian data, dan penarikan kesimpulan. Reduksi data adalah mengumpulkan dari seluruh data melalui wawancara yang didapat untuk dilakukan pemilahan data yang dianggap penting. Data yang direduksi adalah semua data yang termasuk dalam masalah penelitian yang akan digolongkan kedalam uraian singkat terkait masalah penelitian dan akan mengeliminasi data yang tidak perlu digunakan.

Penyajian data bertujuan agar data hasil dari keseluruhan data yang telah dapat diuraikan ke dalam teks atau tabel, selanjutnya menjadi informasi yang relevan dan dapat dilakukan penarikan kesimpulann dari sebuah informasi tersebut. Langkah selanjutnya dari teknik triangulasi yaitu penarikan kesimpulan. Penarikan kesimpulan yaitu kesimpulan dari seluruh data yang telah dianalisis melalui tahapan - tahapan teknik triangualasi yaitu pengumpulan data, reduksi data, penyajian data dan tahapan terkahir adalah menarik kesimpulan dari hasil penelitian dalam bentuk teks dengan tujuan penelitian. Berikut Gambar 2 yang menjelaskan alur dari teknik triangulasi.

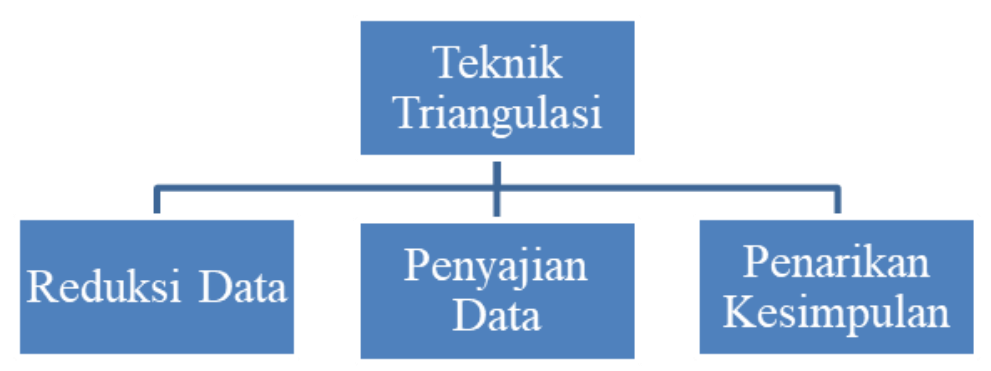

Gambar 2 Teknik Analisis Data

\section{Hasil dan pembahasan}

Gambaran Objek Penelitian

Desa Sepakung terbagi menjadi 12 dusun yang terdiri Dusun Krajan, Dusun Pager Gedok, Dusun Watulawang, Dusun Gojati, Dusun Bungkah, Dusun Sepakung Wetan, Dusun Batur, Dusun Gowono, Dusun Nglimut, Dusun Kenongo, Dusun Jingkol, dan Dusun Srandil yang terletak di terletak di Kecamatan Banyubiru, Kabupaten Semarang. Desa ini memiliki visi sebagai "Mewujudkan Desa Sepakung menjadi desa mandiri melalui bidang pertanian, industri kecil, dan wisata desa", serta memiliki misi antara lain : (1) Memperbaiki dan menambah sarana dan prasarana yang dibutuhkan untuk meningkatkan SDM melalui pendidikan formal maupun informal; (2) Bekerja sama dengan petugas penyuluh lapangan untuk meningkatkan hasil pertanian; (3) Meningkatkan usaha pertanian; (4) Meningkatkan dan mengelola Pendapatan Asli Desa; (5) Mewujudkan pemerintah yang baik dan bersih melalui pelaksanaan Otonomi Daerah.

Pada tahun 2015 Pemerintah Republik Indonesia memiliki program untuk membantu memperbaiki pemerataan perekonomian desa yang disebut dengan program dana desa. Dana desa yang disalurkan ke desa - desa bertujuan untuk membiayai penyelenggaraan pemerintahan, pelaksanaan pembangunan, pembinaan kemasyarakatan, dan pemberdayaan masyarakat. Bersamaan dengan program dana desa maka dibentuk suatu Badan Usaha Milik Desa atau disebut BUMDes. BUMDes dibentuk untuk membantu 
pengelolaan keuangan dan membantu meningkatkan usaha - usaha desa. BUMDes Mandiri Jaya yang berada di Desa Sepakung berdiri pada tanggal 27 November tahun 2014, akan tetapi untuk beroperasi tahun 2016. Berdirinya BUMDes Mandiri Jaya untuk membantu meningkatkan pendapatan Asli Desa dalam menyelenggarakan pemerintah dan pendapatan masyarakat desa serta memberikan pelayanan terhadap kebutuhan masyarakat desa. Visi dari BUMDes Mandiri Jaya "Mewujudkan kesejahteraan masyarakat Desa Sepakung melalui pengembangan usaha ekonomi dan pelayanan jasa dengan moto "Mari Bersama Membangun Desa" dan misi dari BUMDes Mandiri Jaya antara lain: (1) Pengembangan usaha ekonomi melalui usaha simpan pinjam syariah dan usaha sektor riil; (2) Pengembangan ekonomi desa melalui pendayagunaan potensi desa dan pengelolaan pasar desa; (3) Pemenuhan kebutuhan petani melalui pengadaan pupuk dan benih pertanian serta lumbung padi; (4) mengembangan jaringan kerjasama bidang ekonomi produktif dengan berbagai pihak; (5) mengelola dana program yang masuk ke desa bersifat dana bergulir terutama dalam rangka pengentasan kemiskinan dan pengembangan usaha ekonomi perdesaan; (6) menumbuhkembangkan usaha - usaha industri rumah tangga yang produktif dalam meningkatkan kesejahteraan masyarakat Desa Sepakung; (7) Penggalian dan pengelolaan potensi wisata alam dan budaya yang dapat dikembangkan.

Kepemilikan pendirian BUMDes Mandiri Jaya dimiliki oleh pemerintah desa dan masyarakat dengan komposisi 49\% dengan mayoritas kepemilikan adalah pemerintah desa. Struktur organisasi BUMDes Mandiri Jaya terdiri dari komisaris, badan pengurus/pengelola, dan badan pengawas. Pemilihan pengurus dilakukan dengan musyawarah desa, tahapan selanjutnya dengan ditetapkan Surat Keputusan Kepala Desa. Salah satu syarat menjadi pengurus adalah minimal pendidikan SLTA. Pengelolaan BUMDes Mandiri Jaya yang bertugas sebagai pelindung adalah kepala desa, BPD Desa Sepakung bertugas sebagai pengawas, penasehat ditugaskan kepada Bapak Muhammad Sa'dullah, penanggungjawab oleh Bapak Susiyanto Pandu, sekretaris ditugaskan kepada Muhammad Najib, dan bendahara oleh Ibu Atik Rahmawati. Selain pengelola umum juga di bagi kedalam pengelola unit usaha yaitu terdapat kepala unit usaha pariwisata oleh Bapak Saifudin, kepala unit jaringan internet dipegang oleh Bapak Nurodi, dan terakhir kepala unit warung BUMDes ditugaskan oleh Ibu Atik Rahmawati.

\section{Peran BUMDes Mandiri Jaya dalam Meningkatkan Perekonomian Desa}

Peran adanya BUMDes dalam rangka mencapai tujuan untuk meningkatkan perekonomian desa ditunjukkan dengan program pinjaman modal untuk usaha warung, dengan tujuan membantu pemerataan ekonomi dan meningkatkan perekonomian yang ada di Desa Sepakung. Sebagian masyarakat membuka usaha warung untuk membantu menambah penghasilan. Akan tetapi usaha warung satu dengan usaha warung lainnya letaknya cukup jauh. Warung yang dimiliki setiap dusun berbeda - beda, terdapat usaha warung yang masih sangat sederhana dan sudah berkembang. Dusun Krajan termasuk dusun yang lebih berkembang dari dusun yang lainnya karena letak Dusun Krajan berada di sekitar kantor Balai Desa Sepakung.

Sedangkan untuk Dusun Pager Gedok jaraknya sangat jauh dengan balai desa membuat dusun ini sedikit tertinggal pembangunan infrastruktur dan ekonominya. Untuk mengatasi hal tersebut, BUMDes Mandiri Jaya membuat program pinjaman modal usaha warung untuk membantu pemerataan ekonomi dan meningkatkan perekonomian desa. Diharapkan masyarakat dapat membuka usaha warung untuk menambah penghasilan masyarakat. Program pinjaman modal yang ditawarkan oleh BUMDes Mandiri Jaya memiliki pengembalian modal dengan bunga yang rendah. Usaha warung skala kecil modal yang dapat dipinjam maksimal sebesar Rp 1.000.000 dengan bunga pengembalian sebesar $0 \%$ dan $1 \%$ untuk pengembalian modal dengan modal yang dapat dipinjamkan lebih dari Rp 1.000.0000. Tetapi jumlah peminjam modal dibatasi oleh BUMDes Mandiri Jaya dikarenakan jumlah dana yang dimiliki masih terbatas. Jika tidak terdapat pembatasan numlah peminjam maka dikhawatirkan BUMDes Mandiri Jaya tidak dapat menjalankan program yang lainnya untuk membantu meningkatkan perekonomian desa.

Tujuan lain dari program pinjaman dana yang sudah dijelaskan diatas juga untuk membantu usaha warung yang dimiliki masyarakat agar tetap dapat terus beroperasi dan berkembang. Jika usaha semakin berkembang maka penghasilan masyarakat juga akan meningkat dan perekonomian masyarakat juga meningkat. Selain itu peminjam modal juga dengan cepat dapat mengembalikan modal yang sudah dipinjam untuk pengembangkan usahanya. Hal tersebut juga berdampak bagi BUMDes Mandiri Jaya, jika dana yang dipinjamkan sudah kembali maka BUMDes dapat menjalankan program - program BUMDes yang lainnya.

Hasil wawancara dengan sebagian masyarakat bahwa masyarakat sudah mengetahui dan merasakan dampak adanya program BUMDes Mandiri Jaya tentang program pinjaman modal usaha. Dampak yang dirasakan oleh masyrakat berupa mudahnya mendapatkan pinjaman modal untuk mengembangkan usahanya. BUMDes Mandiri Jaya bersedia membantu memberikan pinjaman modal untuk pelaku usaha warung tersebut dengan tujuan untuk membantu meningkatkan perekonomian 
masyarakat Desa Sepakung. Selain itu masyarakat mendapat fasilitas kemudahan lainnya berupa bunga yang rendah dengan syarakat dan ketentuan yang berlaku berdasarkan penjelasan sebelumnya yaitu bunga pengembalian modal sebesar $0 \%$ dan $1 \%$.

Peran BUMDes Mandiri Jaya dalam Mengoptimalkan Aset Desa Agar Bermanfaat Untuk Kesejahteraan Desa

Peran BUMDes Mandiri Jaya dalam mengoptimalkan aset desa dengan mengajak pengelola wisata yang ada di Desa Sepakung melakukan studi banding ke objek wisata Umbul Ponggok Klaten. Dengan harapan ilmu yang didapatkan bisa di implementasikan di Desa Sepakung dalam pengelolaan desa wisata. Potensi yang dimiliki oleh Desa Sepakung kemudian dimanfaatkan oleh masyrakat desa untuk membangun sebuah objek wisata alam dengan memanfaatkan pemandangan alam Gunung Telomoyo. Objek wisata yang dimiliki oleh Desa Sepakung saat itu terdapat 5 objek wisata yaitu Objek wisata Kali Kulon, Cemoro Sewu, Klarasan Hill, Gumuk Reco, dan Air Terjun Goa Semar. Objek wisata yang dikelola oleh BUMDes Mandiri Jaya saat ini hanya Cemoro Sewu dan Gumuk Reco karena ketiga objek wisata yang lain sudah tidak lagi beroperasi.

Objek wisata Kali Kulon terdapat sebuah pohon besar yang dirubah menjadi rumah pohon. Rumah pohon tersebut berada pada dekat dengan kawasan persawahan yang akan memberikan nilai tambah untuk keindahan dari objwk wisata Kali Kulon. Selain itu para pengunjung juga dapat berfoto di rumah pohon. Harga tiket masuk ke lokasi pengunjung hanya perlu membayar seharga Rp 4.000. Selanjutnya Wisata alam Cemoro Sewu terletak di Dusun Jingkol. Wisata Cemoro Sewu menawarkan wisata alam berupa pemandangan alam Gunung Telomoyo. Pengunjung dapat menikmati pemandangan alam dari ketinggian dan dapat melakukan foto dengan latar belakang pemandangan alam gunung Telomoyo. Harga tiket masuk yang ditawarkan yaitu Rp 8.000.

Berikutnya ada Wisata Klarasan Hill adalah tempat didataran tinggi Desa Sepakung yang menawarkan spot foto dengan pemandangan yang sangat indah. Selain itu ada wisata Gumuk Reco yang memiliki beberapa spot foto yaitu ada ayunan langit, ondo langit, dan panjat tebing. Ayunan langit adalah spot foto pertama kali yang ada di wisata Gumuk Reco. Harga tiket masuk lokasi hanya Rp 9.000/orang. Semakin banyaknya pengunjung yang datang maka pendapatan dari Gumuk Reco meningkat terlebih saat hari libur pendapatan bisa naik hingga 4 kali lipat dari hari biasa. Pendapatan dari ayunan langit dibuatlah spot yang lainnya berupa ondo langit dan panjat tebing. Sewa alat keamanan panjat tebing hanya dihargai senilai $\mathrm{Rp} 15.000$.

Terakhir adalah wisata Air Terjun Goa Semar yang terletak di Dusun Srandil. Wisata ini berupa pemandangan air terjun yang berasal dari mata air alami Desa Sepakung. Tiket masuk yang ditawarkan juga terjangkau senilai Rp 5.000. Tetapi dari kelima objek wisata yang ada sampai sekarang hanya objek wisata Gumuk Reco dan Cemoro Sewu yang masih aktif beroperasi dan menjadi kunjungan wisatawan. Tidak beroperasinya ketiga objek wisata Air Terjun Goa Semar, Klarasan Hill, dan Kali Kulon karena kurangnya pengembangan wisata dengan baik dan pengembangan inovasi untuk memajukan wisata.

BUMDes Mandiri Jaya membantu mengoptimalkan aset desa agar bermanfaat untuk kesejahteraan masyarakat dengan melakukan pengoptimalan pemanfaatan kekayaan yang dimiliki oleh desa yaitu pengembangan potensi desa wisata. Pengembangan yang dilakukan dengan melakukan studi banding ke desa wisata Umbul Ponggok. Studi banding ke Umbul Ponggok diikuti oleh seluruh pengurus BUMDes, seluruh Perangkat Desa Sepakung, POKDARWIS, dan sebagian warga masyarakat yang mengelola objek wisata Desa Sepakung. Tujuan melakukan studi banding adalah untuk belajar mengenai pengelolaan desa wisata yang ada di Umbul Ponggok yang nanti ilmunya bisa diterapkan di Desa Sepakung.

Setelah melakukan wawancara dengan pengelola sebagai penanggungjawab BUMDes Mandiri Jaya dilakukan konfirmasi kepada salah satu pengelola objek wisata agar mendapatkan informasi yang dibutuhkan mengenai program BUMDes Mandiri Jaya dalam membantu pengelolaan objek wisata yang ada di Desa Sepakung. Hasil wawancara yang didapatkan dengan pengelola objek wisata Gumuk Reco berpendapat jika studi bading yang diselenggarakan pada tahun 2018 bertujuan untuk membantu pengembangan objek wisata yanga ada di Desa Sepakung. Namun tidak semua yang didapat di objek wisata Umbul Ponggok dapat diterapkan di Desa Sepakung karena letak geografis yang dimiliki berbeda.

Peran BUMDes Mandiri Jaya dalam Meningkatkan Usaha Masyarakat dalam Pengelolaan Potensi Ekonomi Desa

Peran BUMDes untuk mencapai tujuannya dalam meningkatkan usaha masyarakat salah satunya dengan cara membantu memasarkan usaha masyarakat. Di Desa Sepakung terdapat usaha masyarakat yaitu usaha gula semut, gula aren, kripik, dan souvenir. BUMDes Mandiri Jaya membantu agar usaha yang dimiliki oleh masyarakat dapat meningkat dan dapat menjadi sumber penghasilan dengan melakukan pemasaran hasil usaha masyarakat melalui media online seperti instagram dan facebook. Namun 
berdasarkan hasil wawancara dengan Pengelola BUMDes Mandiri Jaya yang ada di Desa Sepakung, belum dapat mengembangkan usahanya melalui media online dikarenakan terbatasnya persediaan hasil usaha yang ada.

Peran BUMDes Mandiri Jaya Mengembangkan Rencana Kerja Sama Usaha Antar Desa dan/atau dengan Pihak Ketiga

Pengembangan rencana kerja dengan pihak ketiga dilakukan oleh BUMDes Mandiri Jaya dengan bekerja sama dengan pasar tradisional untuk penyaluran hasil pertanian milik masyarakat. Selain bekerja sama dengan pasar tradisional BUMDes Mandiri Jaya juga bekerjasama dengan agen BNI 46 sebagai penyalur dana dari pemerintah dalam melakukan penyaluran bantuan berupa sembako kepada masyarakat yang membutuhkan. Untuk terwujudnya peran BUMDes Mandiri Jaya dalam mengembangakan rencana kerja sama antar desa, kedepannya BUMDes berupaya menjadi penyalur hasil pertanian masyarakat ke pasar tradisional. Agar masyarakat tidak menjual hasil pertanian ke tengkulak dengan harga yang sangat rendah. Namun upaya tersebut belum dapat dilakukan karena sebelum adanya BUMDes Mandiri Jaya masyarakat sudah menjual hasil pertaniannya kepada para tengkulak yang berdatangan ke rumah petani. Berdasarkan dari hasil wawancara dengan salah seorang warga sebagian masyarakat memilih menjual hasil panennya kepada tengkulak, tetapi juga terdapat masyarakat yang menjual hasil panennya ke pasar tradisional.

Selain menjadi penyalur hasil pertanian ke pasar tradisional, BUMDes Mandiri Jaya juga sebagai penyalur bantuan sembako melalui kerja sama dengan agen BNI 46 dan pemerintah sebagai pemberi bantuan kepada masyarakat berupa bantuan beras sebanyak $5 \mathrm{~kg}$ dan $1 \mathrm{~kg}$ telur. Tujuan program tersebut adalah pemerintah ingin membantu pemerataan ekonomi dalam bentuk pangan kepada masyarakat yang kurang mampu. Bantuan tersebut dapat diambil setiap sebulan sekali dengan menunggu informasi dari pengelola BUMDes Mandiri Jaya. Berdasarkan hasil wawancara dengan masyrakat program tersebut telah membantu masyarakat yang membutuhkan bantuan pangan tersebut.

Peran BUMDes Mandiri Jaya dalam Menciptakan Peluang dan Jaringan Pasar yang Mendukung Kebutuhan Layanan Umum Warga

Terwujudnya tujuan BUMDes Mandiri Jaya dalam menciptakan peluang dan jaringan pasar. BUMDes dapat menjadi wadah penyedia jasa layanan listrik, tabungan dan simpan pinjam, atau pasar desa berbasis online. Tujuannya untuk mempermudah masyarakat desa menerima pelayanan umum. Di Desa Sepakung BUM Desa memiliki program simpan pinjam dan tabungan yang bekerja sama agen BNI 46. Selain itu masyarakat juga dapat menabung ataupun melakukan pinjaman modal dengan bunga yang rendah yaitu 1\%. Namun dengan bunga yang masih rendah kenyataannya masyarakat belum banyak yang tertarik dengan program BUMDes Mandiri Jaya Sepakung yang bekerja sama dengan agen BNI 46. Karena sebelum adanya agen BNI 46 salah seorang warga yang memiliki warung usaha berkembang sudah menawarkan tabungan dan simpan pinjam dengan bekerja sama dengan agen BRI dengan bunga yang lebih rendah yaitu 0,5\% tanpa syarat dibandingkan dengan agen BNI 46 sebesar $1 \%$.

Adanya simpan pinjam yang diberikan BUMDes kepada masyarakat desa. Membantu pemerataan ekonomi desa dan warung usaha yang membutuhkan modal untuk agar tetap beroperasi saat tidak memiliki modal. Masyarakat merasakan kemudahan peminjaman modal melalui BUMDes Mandiri Jaya daripada melalui bank, karena bunga pengembalian modal sangat ringan yaitu $0 \%$ bagi peminjam modal kurang dari Rp 1.000.000 dan 1\% bagi peminjam lebih dari Rp 1.000.000. Tetapi terdapat warga yang rumahnya jauh dari balai desa dan kantor BUMDes yaitu berada di Dusun Jingkol. Tidak semua masyarakat mengetahui keberadaan BUMDes dan aktivitasnya. Seperti program bumdes simoan pinjam salah satu masyarakat yang menjadi narasumber beliau tidak tahu bahwa BUMDes memiliki program tersebut.

Peran BUM Desa Mandiri Jaya Sepakung dalam Membuka Lapangan Pekerjaan

BUMDes Mandiri Jaya harus bisa menjadi wadah untuk membuka lapangan pekerjaan bagi masyarakat. Desa Sepakung termasuk desa wisata maka dapat dimanfaatkan untuk membuka lapangan pekerjaan bagi masyarakat desa sebagai pengelola dan penjaga tiket masuk wisata dan menjual voucher wifi. Pembagian hasil penjualan voucher wifi untuk warung atau objek wisata sebesar $25 \%$ dari penjualan voucer dan 75\% dikelola oleh pihak BUMDes Mandiri Jaya. Selain itu penjaga tiket masuk dan penjaga spot foto dilakukan oleh masyarakat Desa Sepakung. Diharapkan dapat membantu membuka lapangan pekerjaan bagi masyarakat Desa Sepakung dan menurunkan tingkat pengangguran. Pengelola wisata Cemoro Sewu juga beranggapan jika BUMDes Mandiri Jaya telah membantu membuka lapangan pekerjaan bagi masyarakat desa dengan memberikan pengelolaan wisata sepenuhnya kepada masyarakat desa dengan menjaga loket tiket masuk wisata. 
Peran BUMDes Mandiri Jaya dalam Meningkatkan Kesejahteraan Masyarakat Melalui Perbaikan Pelayanan Umum, Pertumbuhan dan Pemerataan Ekonomi Desa

BUMDes Mandiri Jaya meningkatkan kesejahteraan masyarakat melalui perbaikan layanan umum dengan melakukan pengecekan tersedianya MCK yang bersih dan baik bagi masyarakat, tersedianya air bersih, dan jaringan wifi. Layanan umum yang berada di Desa Sepakung dapat dikatakan sudah baik. Mulai dari MCK yang sudah bersih dan baik, serta terdapat pengecekan MCK dilakukan oleh petugas kesehatan langsung tiap 3 bulan sekali. Warga juga berpendapat bahwa MCK yang dimilikinya saat ini sudah baik. Pada bulan kemarin petugas kesehatan datang ke rumah warga untuk melakukan pemeriksaan MCK yang ada dirumah setiap warga di Desa Sepakung.

Masyarakat tidak perlu mengkhawatirkan ketersediaan air bersih, karena Desa Sepakung memiliki sumber mata air yang berasal dari pegunungan. Cara penyaluran air bersih kerumah warga dengan pemasangan pipa - pipa yang diambil dari tampungan air yang sudah dibuat oleh warga di dekat mata air yang selanjutnya akan disalurkan ke rumah - rumah warga. Layanan umum berupa pemasangan jaringan wifi, karena di Desa Sepakung termasuk kawasan tanpa jaringan, BUMDes Mandiri Jaya melakukan pemasangan pemancar jaringan wifi disetiap titik dusun. Yang tujuannya dapat membantu masyarakat desa untuk mempermudah menerima informasi yang ada di desa dan juga komunikasi antar masyarakat.

Peran BUM Desa Mandiri Jaya Sepakung dalam Meningkatkan Pendapatan masyarakat desa dan Pendapatan Asli Desa

Untuk meningkatkan pendapatan masyarakat desa dan Pendapatan Asli Desa BUMDesa Mandiri Jaya Sepakung melakukan menyediakan voucher wifi yang dapat diperoleh di warung - warung terdekat dengan berbagai macam harga yaitu $5 \mathrm{rb} / 3 \mathrm{jam}, 15 \mathrm{rb} / 7$ hari, dan 30rb/30 hari. Adanya usaha penjualan voucher wifi yang dimiliki oleh desa dapat meningkatkan pendapatan asli desa di Desa Sepakung. Selain itu BUMDes Mandiri Jaya melakukan pemasaran objek wisata Desa Sepakung melalui media instargam untuk menarik pengunjung untuk tertarik datang ke objek wisata yang ada di Desa Sepakung. Pemasaran objek wisata yang dilakukan oleh BUM Desa sudah berhasil karena pengunjung yang berdatangan terutama dihari libur dapat meningkat hingga 3 kali lipat dari hari biasa, dengan demikian penghasilan dari objek wisata juga semakin meningkat dari penjualan tiket parkir dan tiket masuk ke objek wisata. Total dari keseluruhan pendapatan wisata 30\% akan diberikan ke Pendapatan Asli Desa. Menurut penjaga loket tiket memang benar bahwa pengunjung di hari libur bisa mencapai 3 kali lipat dari hari biasanya.

Peran BUMDes Mandiri Jaya secara umum sudah dilakukan sesuai dengan Peraturan Menteri Desa Pembangunan Daerah Tertinggal, dan Transmigrasi Republik Indonesia Nomor 4 Tahun 2015 Pasal 2. Namun dilihat dari seluruh perannya, analisis yang dilakukan masih terdapat kendala dalam implementasi peran BUMDes Mandiri Jaya sebagai wadah penyalur rencana kerja sama antar desa untuk meningkatkan usaha masyarakat. Salah satu yang perlu dilakukan BUMDes adalah sebagai penyalur hasil pertanian masyarakat desa kepada pasar tradisional dengan bekerja sama dengan pemerintah kabupaten. Selain itu keberadaan BUMDes Mandiri Jaya juga belum nampak oleh masyarakat. Hal tersebut didukung dengan peran yang dilakukan oleh BUMDes Mandiri Jaya menurut masyarakat adalah aktivitas dari pemerintah desa. Jadi masyarakat belum mengetahui bahwa BUMDes Mandiri Jaya berdiri sebagai lembaga sendiri bukan menyatu dengan pemerintahan desa.

Keberadaan BUMDes Mandiri Jaya bagi sebagian masyarakat masih belum banyak yang memahami, begitupula dengan program - program yang dimiliki oleh BUMDes Mandiri Jaya yang bertujuan untuk meningkatkan perekonomian desa. Peminjaman dana untuk usaha warung menjadi salah satu contoh program yang dicanangkan BUMDes Mandiri Jaya. Akan tetapi bagi masyarakat yang mengetahui program pinjaman modal usaha warung sudah merasa terbantu berbeda dengan masyarakat yang tidak mengetahui program tersebut. Permasalahan kurangnya pemahaman masyarakat mengenai BUMDes adalah tidak meratanya sosialisai yang dilakukan pihak BUMDes Mandiri Jaya serta perangkat desa karena tehambat oleh jangkauan wilayah yang terlalu luas dan juga jarak antara satu dusun dengan dusun lainnya.

BUMDes sudah berusaha dalam membantu masyarakat pemiik usaha mikro untuk dapat membantu memasarkan hasil produksinya melalui media online, akan tetapi dari hasil wawancara dengan BUMDes Mandiri Jaya mereka memiliki kendala bahwa pemilik usaha mikro belum sanggup untuk melakukan pemasaran hasil produksi usahanya lewat media sosial, karena jumlah hasil produksi yang tersedia tidak cukup besar untuk mengikuti jumlah permintaan konsumen. Namun tidak hanya itu saja kendala yang dihadapi Desa Sepakung, namun BUMDes Mandiri Jaya terdapat kelemahan lain. Kelemahan lain adalah masalah terbatasnya ketersediaan modal yang dimiliki oleh BUMDes Mandiri Jaya. Karena modal adalah faktor utama dalam penggerak jalannya program - program BUMDes Mandiri Jaya. Jika membutuhkan dana yang cukup besar maka BUMDes harus melalukan pembuatan proposal anggaran yamg diserahkan 
kepada kepala desa untuk meminta persetujuan anggaran. Selain terdapat kelemahan pada ketersediaan modal yang dimiliki, juga terdapat kendala pada kurangnya pemahaman tentang BUMDes bagi pengelola BUMDes itu sendiri. Dikarenakan pergantian pengurus yang baru.

Selain itu juga terdapat kendala bahwa POKDRWIS dan BUMDes Mandiri Jaya tidak pernah menemukan titik temu dalam memberikan inovasi baru untuk pengembangan wisata. Serta laporan bagi hasil dari pendapatan wisata yang diserahkan kepada pemerintah para pengelola tidak pernah tahu untuk apa saja pendapatan tersebut. Hal tersebut dapat terjadi karena kurangnya sosialisasi tentang keberadaan BUMDes yang ada di Desa Sepakung keseluruh masyarakat

\section{Simpulan dan saran}

Secara umum sesuai Peraturan Menteri Desa, Pembangunan Daerah Tertinggal, dan Transmigrasi Republik Indonesia Nomor 4 Tahun 2015 bahwa semua peran BUMDes sudah berusaha dilakukan oleh BUMDes Mandiri Jaya. Namun masih terdapat kendala yang dihadapi oleh BUMDes Mandiri Jaya. Kendala yang dihadapi yaitu belum terlaksannya wadah penyalur hasil pertanian desa ke pasar tradisional, kurangnya pemahaman pengelola tentang BUMDes itu sendiri, keberadaan BUMDes Mandiri belum diketahui oleh masyarakat sekitar, terbatasnya modal yang dimiliki oleh BUMDes Mandiri Jaya, serta kendala dalam menemukan kesepakatan bersama untuk ide pengembangan objek wisata yang di Desa Sepakung.

Keterbatasan penelitian ini adanya pergantian pengelola BUMDes Mandiri Jaya pada saat melakukan penelitian, membuat informasi yang didapatkan kurang lengkap. Selain itu sulitnya mencari narasumber yang memahami tentang BUMDes disebabkan kurangnya masyarakat dalam mengetahui tentang keberadaan dan peran BUMDes. Bagi penelitian selanjutnya diharapkan melakukan identifikasi kendala secara lebih detail dalam pengelolaan BUMDes serta memperluas narasumber guna untuk mendapatkan informasi yang lengkap.

\section{Daftar Rujukan}

Agunggunanto, Yusuf, and Darwanto. 2016. "Pengembangan Desa Mandiri Melalui Pengelolaan Badan Usaha Milik Desa (BUMDes)." Jurnal Dinamika Ekonomi Dan Bisnis 13 (No 1): 67-81.

Hayyuna, Rizka, Ratih Nur Pratiwi, and Lely Indah Mindarti. 2014. "Strategi Manajemen Aset BUMDES Dalam Rangka Meningkatkan Pendapatan Desa (Studi Pada BUMDES Di Desa Sekapuk Kecamatan Ujungpangkah, Kabupaten Gresik)." Jurnal Administrasi Publik 2 (1): 1-5.

Ida. 2016. "Desa Miskin Masuk Nominasi Terbaik Sejateng." Radar Semarang, 2016. http://radarsemarang.com/2016/05/25/desa-miskin-masuk-nominasi-terbaik-se-jateng/.

Irvan. 2019. "9 Warga Tubmonas Lapor Dugaan Korupsi Dana Desa Ke Kejaksaan," 2019. https://voxntt.com/2019/02/04/9-warga-tubmonas-lapor-dugaan-korupsi-dana-desa-kekejaksaan/40587/.

Kurniasih, Denok. 2014. "Problem Pengelolaan Badan Usaha Milik Desa (Bumdes) Di Kabupaten Banyumas." Jurnal Administrasi Publik Dan Politik I (III): 182-88.

Nazar, Nurdin. 2016. “Ganjar: BUMDes Yang Sukses Ini Inspiratif, Bisa Jadi Rujukan.” Kompas.Com, 2016. https://regional.kompas.com/read/2016/06/15/15370001/Ganjar.BUMDes.yang.Sukses.Ini.Inspir atif.Bisa.Jadi.Rujukan.

Pemerintah Republik Indonesia. 2014a. Peraturan Pemerintah Republik Indonesia No 60 Tahun 2014 Tentang Dana Desa Yang Bersumber Dari Anggaran Pendapatan Dan Belanja Negara.

Pemerintah Republik Indonesia. 2014b. Undang - Undang Republik Indonesia Nomor 6 Tahun 2014 Tentang Desa. Salinan Undang - Undang No 6 Tahun 2014.

Pemerintah Republik Indonesia. 2015. Peraturan Menteri Desa, Pembangunan Daerah Tertinggal, Dan Transmigrasi Republik Indonesia Nomor 4 Tahun 2015 Tentang Pendirian, Pengurusan Dan Pengelolaan, Dan Pembubaran Badan Usaha Milik Desa. 
Ramadana, Coristya Berlian, Heru Ribawanto, and Suwondo. 2013. "Keberadaan Badan Usaha Milik Desa (BUMDes) Sebagai Penguatan Ekonomi Desa (Studi Di Desa Landungsari, Kecamatan Dau, Kabupaten Malang)." Jurnal Administrasi Publik (JAP) 53 (9): 1689-99. https://doi.org/10.1017/CB09781107415324.004. 